\title{
THE INFLUENCE OF EARNING ZAKAT DISTRIBUTION LEVEL ON ZAKAT MUSTAHIK BUSINESS PROFIT
}

\author{
Ahmad Agung \\ Institut Agama Islam Darussalam (IAID) Ciamis-Jawa Barat \\ Email: ahmad.agung@iaid.ac.id \\ Yati Hilmi \\ Institut Agama Islam Darussalam (IAID) Ciamis-Jawa Barat \\ Asri Awaliyah Fitri \\ Institut Agama Islam Darussalam (IAID) Ciamis-Jawa Barat

\begin{abstract}
This research is motivated by the administration that has not been well organized and the absence of training for BMT and mustahik recipients of productive zakat funds by the National Amil Zakat Agency (BAZNAS) Ciamis Regency. Quantitative field research using a simple linear regression method uses a sample of 30 people. The results showed that (1) Most respondents agreed that the utilization of productive zakat funds at BAZNAS Ciamis Regency through BMT-BMT in Cijeunjing District was quite good. (2) Most respondents agree that the empowerment of mustahik at BAZNAS in Ciamis Regency through BMT-BMT in Cijeunjing District is quite good. (3) The variable utilization of productive zakat funds (X) does not affect the empowerment of mustahik (Y) BAZNAS Ciamis Regency through BMT-BMT in Cijeunjing District.
\end{abstract}

\begin{abstract}
Abstrak
Penelitian ini dilatarbelakangi oleh administrasi yang belum tertata dengan baik dan belum adanya pelatihan baik terhadap BMT maupun kepada mustahik penerima dana zakat produktif oleh Badan Amil Zakat Nasional (BAZNAS) Kabupaten Ciamis. Penelitian kuantitatif lapangan dengan metode regresi linear sederhana ini menggunakan sampel sebanyak 30 orang. Hasil penelitian menunjukkan bahwa (1) Mayoritas responden setuju bahwa pendayagunaan dana zakat produktif pada BAZNAS Kabupaten Ciamis melalui BMT-BMT di Kecamatan Cijeunjing sudah cukup baik. (2) Sebagian besar repsonden setuju bahwa pemberdayaan mustahik pada BAZNAS Kabupaten Ciamis melalui BMT-BMT di Kecamatan Cijeunjing sudah cukup baik. (3) Variabel pendayagunaan dana zakat produktif (X) tidak berpengaruh terhadap pemberdayaan mustahik (Y) BAZNAS Kabupaten Ciamis melalui BMT-BMT di Kecamatan Cijeunjing.
\end{abstract}

Keywords: Productive Zakat, Empowerment, Empowerment of Mustahik

\section{Introduction}

Poverty is a severe problem for the country's future if it is not taken seriously by the government. The number of poor people in March 2017, according to the Central Statistics Agency (BPS, 2017) reached 27.77 million people. In connection with poverty, a rural development expert from England, Robert Chambers, (Suyanto, 2021: 12) that since twenty years ago he concluded that the core of poverty is the existence of a deprivation trap. The poverty trap consists of five misfortunes surrounding poor families: poverty itself, physical weakness, alienation, vulnerability, and powerlessness. 
All of these are interrelated, resulting in a prolonged trap. From some of these misfortunes, the most to be considered are vulnerability and helplessness. The vulnerability causes the poor to have to sell their remaining property to get poorer. Meanwhile, powerlessness is when the poor, due to their weak family position or low level of education, make the poor poorer because they are faced with the authorities' rules or irresponsible rich people.

Islam has a special style to reduce and eradicate poverty, namely with zakat. Zakat is a gift that must be given from a certain set of assets, according to certain characteristics and sizes to certain groups entitled to receive it (Nakhrawie, 2019: 14). While productive zakat is zakat that provides profitable results and will continue to grow. According to Qardawi (2010: 1118) that zakat is a social system, because it functions to save people from weakness either due to innate or due to circumstances, to cope with various disasters and accidents, to provide humanitarian assistance to those who are in need to help those who do not have it, the strength to support the weak, the poor and ibn sabil, and to minimize differences between the rich and the poor.

The distribution of zakat today is generally carried out by zakat institutions in a consumptive way even though this method does not touch the problems faced by mustahik, because it only helps their difficulties for a moment. There is a need for productive zakat funds. The distribution of productive zakat means giving zakat to the poor to be used as business capital to become their livelihood or develop their business. Through this venture capital assistance, it is hoped that they will raise mustahik to open up job opportunities and fulfill their own living needs. A further goal is to make mustahik zakat a muzakki zakat.

Several previous studies have the same theme. One of them, Putra (2010: 79), who analyzed the effect of the utilization of productive zakat funds on the empowerment of mustahik at the Executive Board for Zakat Affairs Amwal Muhammadiyah (BAPELURZAM) Weleri Branch Manager, Kendal Regency, which obtained results from empirical tests that the utilization of productive zakat had a significant effect on the empowerment of mustahik. . In line with the results of Putra's research, Sartika (2008: 87) analyzed the effect of productive zakat utilization on the empowerment of mustahik at the Solo Peduli Foundation LAZ Surakarta. The results of his research state that the utilization of productive zakat funds influences mustahik's income. The results of the two previous studies mentioned above, found that the utilization of productive zakat funds had a significant influence on the empowerment of mustahik. However, the researcher's temporary observation is that there is no effect between the utilization of productive zakat funds on the empowerment of mustahik. There are several reasons for this, including: the administration of BAZNAS in Ciamis Regency has not been collected properly, it can be seen that there is still data that has not been recorded in the database or computer, including data on the economic condition or welfare of the Ciamis community and details of the names or number of mustahik recipients of productive zakat funds through BMT. Scattered, so it is necessary to seek information from the relevant BMT.

Furthermore, in implementing the utilization of productive zakat funds, BAZNAS Ciamis Regency still relies more on BMT. And there is no optimal training and coaching for mustahik or BMT. Thus, the researchers' temporary observations show that there is no influence between the utilization of productive zakat funds on the empowerment of mustahik. Based on this background, researchers are interested in researching the 
effect of productive zakat utilization on the empowerment of mustahik in BAZNAS, Ciamis Regency.

\section{Theoretical Review}

\section{Zakat and Productive Zakat Fund Utilization Concept}

The word zakat, when viewed in terms of language, has several meanings including blessing (al-barakah), growth (an-nama'), clean (at-thaharah), goodness (as-salah), clarity of something (safwatu asy ya`), and praise (al-madu). Zakat also means tazkiyah (purify). In terms of zakat is defined as a part of property with certain conditions that are required for the owner to be handed over to those who are entitled to receive it, with certain conditions as well.

Zakat is the 3rd pillar of Islam after prayer. On this basis, zakat is obligatory if the property of a Muslim or institution has reached the haul (even one year) and reaches the nisab (minimum standard of total assets). As for the evidence of the Qur'an mentioned in Q.S. At-Taubah: 103, namely: "Take zakat from some of their wealth, with that zakat you cleanse (clear them from stinginess and excessive love for property) and purify (fertilize the qualities of goodness in their hearts and develop wealth). their things) them and pray for them. Verily, your prayer (becomes) peace of soul for them. And Allah is All-Hearing, All-Knowing." (Jumanatul 'Ali, 2004: 204)

The functions and objectives of zakat include: helping to ease the burdens of our brothers and sisters who are not able to afford, equitable distribution of income between the rich and the poor, which means minimizing inequality and expanding or strengthening the ties of brotherhood and friendship among Muslims or human beings in general. As for the provisions of muzaki or people who pay zakat, among others: intelligent, mature, and a Muslim. Meanwhile, the provisions for the goods to be zakah include: assets are fully controlled, derived from businesses where it is possible to take advantage of them, their assets develop, and are free from debt. (Nakhrawi, 2019: 14). Zakat recipients, as mentioned in Q.S. At-Taubah: 60 namely: indigent, poor, amil (people who manage and distribute zakat funds), converts (people who have just converted to Islam), slaves, debtors (gahrimin), and ibn sabil (people who travel for good intentions)

According to the Big Indonesian Dictionary, utilization means exploitation to be able to bring results and benefits; business (human resources etc) to be able to carry out their duties properly; efficient. According to the Oxford Dictionary, utilization or utility is defined as "useful, especially through being able to perform several functions, which means being useful, especially through the ability to perform several functions. While the word productive is derived from English, namely "productive" which means to produce or give a lot of results (Nakhrawie, 2019: 88-90). So if it is related to zakat, the utilization of productive zakat funds is an effort so that these zakat funds are able to bring benefits to those who use them.

The utilization of zakat is everything related to the government's efforts to utilize the results of zakat collection to be distributed to mustahik (target recipients of zakat) based on sharia, appropriate use, and effective utilization through a distribution pattern that is productive and has benefits following the economic objectives of zakat. . (Permono, 1992: 41) 
The utilization of zakat has been explained in Law No.23 of 2019: (1) Zakat can be utilized for productive efforts in the context of handling the poor and improving the quality of the people. (2) The utilization of zakat for productive business as referred to in paragraph (1) is carried out if the basic needs of mustahik have been met.

Meanwhile, the procedures for utilizing zakat funds in productive activities, according to Nafiah (2015: 312) are (1) conduct a feasibility study; (2) determine the type of productive business; (3) conduct guidance and counseling; (4) carry out monitoring, control and supervision; (5) conduct evaluation; and (6) make a report.

The indicators for the utilization of productive zakat funds include (1) Targets for the Utilization of Productive Zakat Funds (Law No. 23 of 2019). (2) Guidance and Mentoring in Mustahik Business (Ministry of Religion of the Republic of Indonesia, 2020: 77)

\section{Mustahik Empowerment Concept}

Empowerment as a translation of empowerment contains two meanings, namely (1) to give power or authority to or to give power, transfer power, or delegate authority to other parties, (2) to give the ability to or to enable or attempt to give ability or empowerment. According to Suharto (2005: 56), empowerment is a series of activities to strengthen power over the empowerment of weak groups in society by encouraging, motivating, and raising awareness of that potential into real action. Such as individuals who experience a weak or poor economy.

According to the researcher, if it is related to mustahik, namely the community or people who are entitled to receive zakat, then mustahik empowerment is exploring and developing the potential of mustahik to be able to improve their economic conditions. This mustahik empowerment is carried out on the synergy between the BAZNAS (National Amil Zakat Agency) / LAZ (Amil Zakat Institution) with mustahik or with the BMT. So that in this empowerment, the amil institution can make partners independent, so that partners in this case mustahik do not always depend on amil. (Ridwan, 2005: 216-217)

The indicators for empowerment of mustahik include: (1) Mustahik Skills (Wafa, 2003: 7). (2) Mustahik Business Management (Putra, 2010: 29). (3) BAZNAS targets against Mustahik (Nafiah, 2015: 317). BAZNAS, which stands for National Amil Zakat Agency, is an institution that manages zakat nationally. BAZNAS was established, based on the legal basis of establishment in Law no. 23 of 2019 PP No. 14 of 2014. As for the nature of BAZNAS itself, it is independent and responsible directly to the president through the minister of religion. BAZNAS membership consists of 11 members, namely 8 people from elements of society (ulama, professionals, and Islamic community leaders) and three people from government elements. Led by a chairman and a vice-chairman. The term of office of BAZNAS is 5 years and can be re-elected for one term of office. (Ministry of Religion RI, 2020: 27-28) There are several sections of BAZNAS. Among them is provincial BAZNAS, which the minister of religion forms at the governor's suggestion after consideration of BAZNAS (Central), which is responsible to BAZNAS and the province. Meanwhile, Regency/City BAZNAS was formed by the director-general of Islamic community guidance at the Indonesian Ministry of Religion at the suggestion of the regent or mayor after receiving consideration from BAZNAS (Central). (Ministry of Religion of the Republic of Indonesia, 2020: 29) 
Two mandates that must be carried out or carried out by amil institutions, both BAZNAS and LAZ, namely, the mandate as an institution that must empower people and the mandate to make people aware of their obligation to pay tithe. (Ministry of Religion RI, 2020: 63)

\section{Methods}

This research was conducted at BAZNAS Ciamis Regency, West Java with case studies on BMT El-Taqwa, BMT Miftahussalam, and BMT Al-Fattah in Cijeujing District from April 2017 to August 2017. Researchers chose BAZNAS Ciamis Regency because the distribution of productive zakat funds is relatively high. According to secondary data with interviews with BAZNAS administrators on May 21, 2017, it was stated that the distribution of zakat funds reached $80 \%$, with which he got the second rank achievement in the province of West Java in the distribution of zakat funds.

The type of research conducted by the researcher is quantitative research. Quantitative research is a type of research that produces findings that can be achieved (obtained) using statistical procedures or other methods of quantification (measurement) (Sujarweni, 2014: 39). The method used in this study is a descriptive method (descriptive survey), which is a research method that intends to explain the relationship between variables by using hypothesis testing (Sumadi and Sri, 2015: 148). The measurement uses a Likert scale. Likert scale is a scale that is used to measure opinions, perceptions of a person or group about events or social phenomena, variables that are measured or translated into sub-variables and then made indicators (Riduwan, 2005: 86).

The data was collected by observation, interview documentation, and distributing questionnaires. The data analysis used descriptive statistical analysis processing using the SPSS version 16.0 program. The population is mustahik recipients of productive zakat BAZNAS Ciamis Regency at BMT-BMT Cijeunjing District, totaling 30 people. According to Arikunto (1998: 120), which states that if the population is less than 100, then it is better to take all, and if the total population is more significant than 100, it can be taken between $10 \%-15 \%$ or $20 \%-25 \%$ or greater than that. Based on this, the number of respondents in this study was 30 people or the entire population, because the population was less than 100 people.

\section{Results and Discussion}

BAZNAS Ciamis Regency is an institution that was established or rather inaugurated to collect and distribute zakat funds for the Ciamis community. Based on the results of researcher interviews with several administrators of BAZNAS Ciamis Regency, briefly explained that BAZNAS Ciamis Regency was established based on several instructions. Among other things: first, instructions from the regional secretary. Second, instructions from the Regent of Ciamis. Third, the instructions from the local regulations in Law NO. 23 of 2019 concerning zakat management confirm the need for the role of BAZNAS as a non-structural government institution that is independent and accountable to the president through the minister of religion (Basri et al, 2015: 16).

The characteristics of the respondents from the results of the respondent's questionnaire answers, among others: The results obtained that the majority of respondents came from members of BMT Miftahussalam as many as 15 people, 
members of BMT At-Taqwa as many as ten people, and at least five people came from members of BMT Al-Fattah.

\section{Utilization of Productive Zakat Funds}

Target item 1, namely BAZNAS in selecting mustahik, is in accordance with Islamic religious provisions, including $3.3 \%$ of respondents stated strongly agree, 93.3\% agree, and 3.3\% quite agree. In target item 2, BAZNAS puts forward the needy, poor, and other asnaf in the target for the utilization of productive zakat funds, among others: $13.3 \%$ of respondents stated strongly agree, while the remaining $86.7 \%$ agreed. In target item 3, namely BAZNAS providing business capital assistance for mustahik who lack working capital, among others: $26.7 \%$ of respondents stated strongly agree, while $73.3 \%$ agreed. In target 4 , BAZNAS is easy in terms of requirements, fast in service without extortion, among others: $30 \%$ of respondents stated strongly agree, while $70 \%$ agreed. In target 5, namely the productive zakat utilization program, it is very good and appropriate to improve the economic level, in this case the income of mustahik, among others: $16.7 \%$ of respondents stated strongly agree, $60 \%$ agree, $20 \%$ quite agree and $3.3 \%$ do not agree.

Coaching and mentoring item 1, namely BAZNAS provides training tools to stimulate mustahik to have a soul, including $10 \%$ of respondents stated strongly agree, $13.3 \%$ agree, $13.3 \%$ entirely agree, and $56.7 \%$ disagree, and $6,7 \%$ strongly disagree. In the coaching and mentoring item 2, BAZNAS selects the type of business that mustahik is involved in, including $3.3 \%$ of respondents strongly agree, $36.7 \%$ agree, $26.7 \%$ quite agree, and $33.3 \%$ disagree. In the coaching and mentoring item 3, BAZNAS holds regular guidance to find out/control the condition of mustahik businesses, including: $6.7 \%$ of respondents stated strongly agree, $20 \%$ agree, $20 \%$ quite agree and $50 \%$ disagree, and $3.3 \%$ strongly do not agree. In coaching and mentoring 4, BAZNAS evaluates mustahik regarding their business development, including $10 \%$ of respondents strongly agree, $26.7 \%$ agree, $13.3 \%$ quite agree, and 50\% disagree. On item 5 of coaching and mentoring, BAZNAS guides in forming competent human resources in its business, including $3.3 \%$ of respondents strongly agree, $50 \%$ agree, $16.7 \%$ entirely agree and $30 \%$ disagree.

\section{Mustahik Empowerment}

Skill item 1 means that you are aware of the importance of entrepreneurship skills after utilizing productive zakat funds by BAZNAS, including $11.8 \%$ of respondents strongly agree, $70.6 \%$ agree, and $5.6 \%$ quite agree. In skill item 2, you feel your skills have increased in entrepreneurship, including $13.3 \%$ of respondents stated strongly agree, $80 \%$ agree, and $6.7 \%$ quite agree. In skill 3 , you are satisfied that BAZNAS is a trustworthy, transparent and professional Amil Zakat Agency that makes you skilled in entrepreneurship, including $6.7 \%$ of respondents stated strongly agree, $63.3 \%$ agree, $23.3 \%$ quite agree, and $6.7 \%$ disagree.

Management item 1 is that you begin to understand how to manage existing resources for business progress, including $6.7 \%$ of respondents strongly agree, $73.3 \%$ agree and $16.7 \%$ quite agree and $3.3 \%$ disagree. In management item 2, you have started to understand how to manage your business, marketing strategies and business finances, including $6.7 \%$ of respondents stated strongly agree, $70 \%$ agree and $20 \%$ quite agree, and $3.3 \%$ disagree. In management item 3 , you are directed to manage a 
good business, including $3.3 \%$ of respondents strongly agree, 60\% agree, 30\% quite agree, and $6.7 \%$ disagree.

Target item 1 is that you are starting to be able to support your daily needs from the results of these efforts, including $6.7 \%$ of respondents stated strongly agree, $63.3 \%$ agree, $23.3 \%$ quite agree, and $6.7 \%$ disagree. In target 2 , your income gradually increases, including $20 \%$ of respondents strongly agree, $50 \%$ agree, $23.3 \%$ quite agree, and $6.7 \%$ disagree. In target item 3, you can now donate from the results of the utilization of productive zakat funds by BAZNAS, including $10 \%$ of respondents stated strongly agree, $56.7 \%$ agree, and $33.3 \%$ quite agree. In target item 4 , you believe that the productive zakat fund utilization program can be an alternative to reduce powerlessness to become empowered, among others: $10 \%$ of respondents stated strongly agree, $10 \%$ agree and $70 \%$ quite agree, and 20\% disagree.

Simple linear regression model is used to analyze the causal relationship of one independent variable to one dependent variable (Suliyanto, 2019: 39). The following is the result of a simple linear regression equation in this study using SPSS version 16: the constant a value is 36.606 , which means that for every change in the score for the utilization of productive zakat funds, it is estimated that the mustahik empowerment score will increase by 36.606 units in the same direction. While the Standard Error (constant) or deviation of the fixed regression coefficient is 4.939, the Standard Error of productive zakat funds utilization is 0.139, Standard coefficient Beta is 0.64. The tConstant or t-table is 7.411, then the t-utilization of productive zakat funds or t-count is 0.339. At the value of sig. constant $0.00<$ from 0.05 which means significant, but in regression analysis, the most important is the value of sig. of the independent variable. Meanwhile, the value of sig. The utilization of productive zakat funds is $0.737>0.05$, which means that the variable of productive zakat fund utilization has no effect on the empowerment of mustahik.

Based on the results of the t-count value (0.339) < t-table value $(7.441)$ or because of the sig. the utilization of productive zakat funds is $0.737>0.05$, so the results of this study accept Ho and reject Ha. Accept Ho, it means that the variable utilization of productive zakat funds has no significant effect on the empowerment of mustahik.

The results of the determination of R2 obtained a correlation coefficient value of 0.64 or $6.4 \%$, which means that it shows that the productive zakat fund utilization variable has a very weak relationship with mustahik empowerment. The coefficient of determination (R Square) is 0.004 , which means only 0,4\% empowerment of mustahik which can be explained by the independent variable (utilization of productive zakat funds). At the same time, the rest $(100 \%-0.4 \%=99.6 \%)$ is defined by other variables that are not included in this research model.

Previous research conducted by Farid et al, (2015: 1) analyzed the impact of productive zakat distribution on mustahik business profits at the Azka Al Baitul Amien Amil Zakat Institution for the 2021 period, the results of the Simple Regression test with the Ordinary Least Square (OLS) approach stated that the distribution of zakat funds productive does not have a significant effect on profits and business income of mustahik. As for the causes of this, among others: first, mustahik's business is not the only source of income. Second, the average amount of zakat given is very small and tends not to be directly proportional to the size of the mustahik's business. For 
example, mustahik with a business turnover of Rp. 1,500,000,- get zakat funds of Rp. 100,000, - while those with a turnover of Rp. 400,000, - get zakat funds of $\mathrm{Rp}$ 800,000 . It causes zakat to have no impact, let alone the distribution of zakat in the form of loans, meaning that the mustahik must repay the zakat funds within a certain time.

Third, most mustahik's education level is low. 11 out of 13 mustahik have a junior high school education or less. The level of education determines the mindset in developing a business. The absence of records related to mustahik's business activities is one form of low education.

The results of Farid's research are in line with the results of research conducted by researchers who have the same theme. The results of the research by researchers that the utilization of productive zakat funds at BAZNAS Ciamis Regency has a very weak or insignificant effect on the empowerment of mustahik. As for the reason, based on the survey and analysis of researchers, among others: first, the administration at BAZNAS Ciamis Regency has not been properly compiled, it can be seen that there is still data that has not been recorded in the database or computer including data on the economic condition or welfare of the Ciamis community and details of names or numbers. Mustahik recipients of productive zakat funds through BMT are still scattered, so it is necessary to seek information from the relevant BMT. Second, BAZNAS Ciamis Regency relies more on or gives full responsibility to BMTs who are partners in the distribution of productive zakat funds to mustahik, so that the lack of monitoring and guidance either to BMT or mustahik directly affects the utilization of productive zakat funds does not affect mustahik. Third, BAZNAS Ciamis Regency is still not optimal in providing guidance, training and supervision either through BMT or directly to mustahik to implement productive zakat funds utilization. Whereas mustahik still really needs guidance and assistance in providing skills, business management, and training so that mustahik are more directed and monitored to have empowerment.

The conditions mentioned above can be used as evaluation material for BAZNAS Ciamis Regency, especially in the utilization of the next productive zakat funds. First, it is necessary to reorganize the data collection related to the mustahik situation. Second, BAZNAS can actively participate in monitoring the management and development of mustahik business conditions that receive productive zakat funds and the productive zakat funds are managed in the form of grants/non-loans. Third, BAZNAS should provide training, business assistance, and regular coaching to achieve empowerment so that mustahik's condition is monitored.

\section{Conclusion}

Based on the results of research and testing that have been carried out, several conclusions can be drawn, including: (1) In the variable utilization of productive zakat funds BAZNAS Ciamis Regency through BMT-BMT in Cijeunjing District (X) based on the results of the questionnaire score with the majority of respondents in the answer choices quite agreeing and agreeing (numbers 3 and 4, with a total score of 3,53 ) proves that in the utilization of productive zakat funds, it is quite good. However, it needs to be improved a lot, especially in coaching and mentoring. Many answers do not agree; this must be considered because the mustahik process to be efficient requires coaching and mentoring. (2) The mustahik empowerment variable at BAZNAS Ciamis 
Regency through BMT-BMT in Cijeunjing District (Y) based on the results of the questionnaire score with the majority of respondents on the answer choices quite agreeing and agreeing (numbers 3 and 4, with a total score of 3.53 ) proves that the mustahik empowerment is quite good. However, it needs to be improved a lot, especially in the procurement of training tools, many of the answers do not agree. This must be considered because the process of empowering mustahik to have skills is very much needed, especially skills in managing a business. (3) Based on the Simple Linear Regression Test, the variable utilization of productive zakat funds towards the empowerment of mustahik BAZNAS Ciamis Regency through BMT-BMT in Cijeunjing District, namely: t-count value (0.339) < t-table value (7.441) or sig. the utilization of productive zakat funds is $0.737>0.05$, then Ho is accepted, which means that the variable of productive zakat fund utilization has no significant effect on mustahik empowerment.

\section{REFERENCES}

Al-Bukhari, Abu Abdullah Muhammad bin Ismail. (2019). Shahih Al-Bukhari. Jakarta. PT. Niaga Swadaya.

Arikunto, Suharsimi. (1998). Prosedur Penelitian Suatu Pendekatan Praktek. Jakarta: Rineka Cipta.

Arikunto, Suharsimi. (2006). Prosedur penelitian suatu pendekatan praktik. Jakarta: Rineka Cipta.

Basri, Yuswar Zaenul dkk. (2015). Zakat Infak Sedekah dan Akuntansi serta Potensinya dalam Meningkatkan Kesehjateraan Rakyat Miskin. Jakarta. Penerbit Universitas Trisakti.

Farid, Muhamad dkk. (2015). Analisis Dampak Penyaluran Zakat Produktif Terhadap Keuntungan Usaha Mustahik. Jurnal Fakultas Ekonomi, Universitas Jember (UNEJ).

Jumanatul Ali. (2004). Al-Qur'an dan Terjemahnya. Semarang.

Kementerian Agama RI. (2020). Manajemen Pengelolaan Zakat. Kementerian Agama RI Direktorat Jenderal Bimbingan Masyarakat Islam.

Nafiah, Lailiyatun. (2015). Pengaruh Penayguanaan Zakat Produktif Terhadap Kesehjateraan Mustahik Pada Program Ternak Bergulir BAZNAS Kabupaten Gresik. Jurnal El-Qist. Vol. 5. No. 1.

Nakhrawie, Asrifin An. (2019). Sucikan Hati \& Bertambah Kaya Bersama Zakat. Delta Prima Press.

Permono, Sjechul Hadi. (1992). Pendayagunan Zakat Dalam Rangka Pembangunan Nasional. Jakarta. Pustaka Firdaus.

Putra, Ahmad Fajri Panca. (2010). Pengaruh Pendayagunaan Zakat Produktif terhadap Pemberdayaan Mustahik pada Badan Pelaksana Urusan Zakat Amwal Muhammadiyah (BAPELURZAM) Pimpinan Cabang Muhammadiyah Weleri Kabupaten Kendal. Yogyakarta. Skripsi Jurusan Ekonomi Islam.

Qardawi, Yusuf. (2010). Hukum Zakat: Studi Komparatif Mengenai Status dan filsafat berdasarkan Qur'an dan Hadis. Bogor. Pustaka Litera Antar Nusa. 
Riduwan. (2005). Metode dan Teknik Menyusun Tesis cetakan ke-3. Bandung. Alfabeta.

Ridwan, Muhammad. (2005). Manajemen Baitul Maal Wa Tamwil (BMT) cetakan ke2. Yogyakarta. UII Press.

Soemitra, Andri. (2009). Bank \& Lembaga Keuangan Syariah. Jakarta. Kencana Prenada Media Group.

Suharto, Edi. (2005). Membangun Masyarakat Memberdayakan Rakyat. Kajian Strategis Pembangunan Kesehjateraan Sosial \& Pekerjaan Sosial. Bandung. PT. Refika Aditama.

Sujarweni, Wiratna. (2014). Metodologi Penelitian. Yogyakarta. Pustaka Baru Pers.

Suliyanto. (2019). Ekonometrika Terapan: Teori\& Aplikasi dengan SPSS. Yogyakarta. Andi.

Suyanto, Bagong. (2021). Anatomi Kemiskinan dan Strategi Penanganannya. Malang. In-Trans Publishing.

Sumadi dan Sri. (2015). Analisis Faktor-faktor yang mempengaruhi Kinerja Guru Pendidikan Agama Islam SMP Negeri di Kota Tasikamalaya. Ciamis. Program Pasca Sarjana Institut Agama Islam Darussalam. Jurnal Penelitian Pendidikan Islam Vol.3 No.1 Tahun 2015 .

Wafa, Hosnu El. (2003). Konsepsi Zakat Produktif dalam Pemikiran Syekh Muhammad Arsyad Al Banjari (Studi Terhadap Kitab Sabil Al Muhtadin). Skripsi S1. Yogyakarta. UIN Sunan Kalijaga. 